\title{
Disappeared to Ethiopia's Bermuda: Tales by a Puppet
}

\author{
LAUREN VAN DER REDE \\ Centre for Humanities Research and Department of English, University of the Western \\ Cape
}

At the Red Terror Martyrs' Memorial Museum (RTMMM) in Addis Ababa, Ethiopia, there sits upon a wall a chart of the torture houses used during a campaign of terror waged by the Derg regime that ruled Ethiopia from 1974 to 1987. Among the most notable was Bermuda House - named as such because, 'if someone went in there, they would not come back out.' ${ }^{1}$ Alongside the wall chart is a puppet, bound up in strings and rods, that is staged and used to depict the wofe lala torture technique (also known as Technique No. 8 and falanga) ${ }^{2}$ used by the military junta. In this article, I attempt to think through the roles played by the puppet, and by spaces such as Bermuda House, as contributory interlocutors to the grand narrative of the Red Terror as constructed by the museum. In doing so, I consider ways in which the puppet, through its staging and performance, stands proxy for the still missing who disappeared during the Red Terror. I also show how the puppet illustrates an entanglement between genres of missingness while acting on its audiences as its object. The puppet, I argue, as a proxy for the still-missing missed, stages the tension that exists between atrocities that are named as terror in popular discourse but recognised as genocide under Ethiopian law. Furthermore, the puppet stages not only the bleeding of these tensions into one another but also the question of what remains unacknowledged between them. ${ }^{3}$

\section{The Ethiopian Red Terror}

Ethiopia: a country, a space, a nation bound up with the pride of never having been subjected to formal colonisation, but also haunted by a campaign of terror that its own legal institutions recognise as genocide. The Red Terror occurred after the Ethiopian Revolution of 1974 and the consequent dismantling of the monarchy that had been ruled by Emperor Haile Selassie. The revolution occurred in response to the failures of the monarchy - as state - to address the economic and social inequalities embedded in the country's social fabric. These were highlighted by the famine of 1973/1974, which decimated the country, and particularly the peoples living in

\footnotetext{
For their own safety, the names of the people interviewed in Addis Ababa, Ethiopia are withheld.

2 Amnesty International, Ethiopia: Accountability Past and Present: Human Rights in Transition, AI Index, AFR 25/06/95, 1 April 1995, 39, 37, https://www.refworld.org/docid/3ae6a9e3a.html (accessed 24 November 2018).

3 The research on which this paper is based would not have been possible without the Early Career Fellowship I was awarded by the Centre for Humanities Research at the University of the Western Cape; and the assistance of the Institute of Ethiopian Studies at the University of Addis Ababa in Ethiopia, which granted me access to its archive. The aforementioned fellowship forms part of the South African Department of Science and Technology and the National Research Foundation's Flagship Programme for Critical Thought in African Humanities.
} 
Wollo Province in the northeast of the country - a reality that stood in stark opposition to the opulence then being enjoyed by the emperor and his kin. In response, peasants, workers, students and members of the intelligentsia, supported by the military, waged a revolution to overthrow the monarchy and institute democratic rule. Of these, a faction of the military, known as the Derg (or committee) removed the emperor and seized power on 12 September 1974. Despite claiming to represent the peoples of Ethiopia and their political aspirations, and stating that they planned to follow the ideology of Marx and Lenin, the Derg instituted a campaign of terror in Ethiopia. Anyone who criticised or opposed the Derg was subjected to the 'capture and kill campaign' which the military junta waged against anyone they chose to label as 'counter-revolutionaries'. This began shortly after the Derg took control of the state, and was officially instituted in 1977 by their chairperson and head of state, Mengistu Haile Mariam, during a speech in what was then known as Revolution Square. In the speech, Mengistu called for 'death to counter-revolutionaries!' throwing three bottles filled with red liquid into the air to signify 'the blood he vowed to spill of his "enemies"'. Chief among the counter-revolutionaries identified were members of the Ethiopian People's Revolutionary Party (EPRP) - a Marxist opposition group - but many other opposition groups and civilians were also targeted.

Like a number of other political organisations, the EPRP had members of the Ethiopian Student Movement (ESM) at its core. After an attempted coup against the emperor in 1960, the ESM took on a political role, progressing from being 'an organisation at Addis Ababa University representing student concerns on food, housing, and other issues, to the centre of national political dissent. ${ }^{5}$ By the late 1960's, the student movement had endorsed the teachings of Marx, as practised by Mao Zedong and Lenin, and popularly referred to as Marxism-Leninism. ${ }^{6}$ According to Sandra Fullerton Joireman, two of the issues highlighted by the ESM have 'carried through' into political discourse and debate in Ethiopia: the 'self-determination of nationalities and land rights.7 These two issues, claims Joireman, proved divisive in the sense that, in post-revolution Ethiopia, they became major points of disagreement between 'two of the most important political organisations which evolved out of the ESM', namely the EPRP and the All-Ethiopia Socialist Movement (MEISON). ${ }^{8}$ Despite both organisations being class-orientated, the EPRP supported the notion of private land ownership, while MEISON preferred the 'policy of usufruct rights with state ownership' as 'adopted by the Derg.'. Once accused of being counter-revolutionary, the EPRP were marked as a primary enemy of the state, and, as such, much of the Red Terror campaign was directed against its members. The Derg orchestrated and

\footnotetext{
From the RTMMM's website: http://www.rtmmm.org/redterror.html (accessed October 2018).

S. F. Joireman, 'Opposition Politics and Ethnicity in Ethiopia: We Will All Go Down Together', Journal of Modern African Studies, $35,3,1997,389$

Joireman, 'Opposition Politics'.

Joireman, 'Opposition Politics'.

Joireman, 'Opposition Politics', 390. The acronym MEISON derives from the Amharic for All-Ethiopia Socialist Movement.

Joireman, 'Opposition Politics', 390.
} 
facilitated house-to-house searches in which people identified as members of the EPRP were 'taken into custody' and then brought out onto the street and shot. ${ }^{10}$

Officially, the Red Terror is recorded as having taken place between 1977 and 1978, although this period was arguably but the climax of an unfolding of violence that began with the Revolution and continued through democratisation. That is, the violence of 1977 and 1978 was when the most extreme and manifest violence of the Red Terror occurred in all its bloodiness. Into this period, the Derg condensed all its latent violences - persecution, repression and consistent threat of death. ${ }^{11}$ Consider for example the mass killing by the Derg of 60 members of Haile Selassie's regime (including, many believe the emperor himself). Later, members of opposition parties, student organisations and the intelligentsia were systematically targeted and assassinated, most intensely during the purges of 1977 and 1978. During and after these purges, the Derg prohibited the mourning of 'counter-revolutionaries', especially in public and in culturally specific ways. Moreover, should the bereaved families or friends of these murdered persons wish to retrieve their body, they would be required to pay the infamous bullet fee of approximately 125 Birr. $^{12}$ In fact, atrocities committed by the Derg and its supporters continued through the 1980s and into the 1990s, until the regime was finally overthrown and dismantled in 1991. The junta was replaced by a coalition government that was to govern the country through a transition period, after which a democratically elected party was to hold office.

\section{Terror as genocide?}

In the wake of the dissolution of the Derg and its removal from power, the Ethiopian state began to transition towards democracy, led by the Ethiopian People's Revolutionary Democratic Front (EPRDF) - a coalition consisting of the Oromo People's Democratic Organisation, the Amhara National Democratic Movement, the Southern Ethiopian People's Democratic Movement, and the Tigray People's Liberation Front. Despite being clearly stratified by textures of ethnicity, the EPRDF, as a transitional government, gestured towards national reconciliation by establishing a Special Prosecutor's Office on 8 August 1992, as provided for by Proclamation 22/1992. However, it was October 1994 before an announcement was made that charges would be laid against former members of the Derg. The charges covered over

10 See: A. L. Mahoney, (ed.) Documenting the Red Terror: Bearing Witness to Ethiopia's Lost Generation, (Ottawa: Ethiopian Red Terror Documentation and Research Centre, 2012); see also R. Gellately, and B. Kiernan (eds), The Specter of Genocide: Mass Murder in Historical Perspective (Cambridge: Cambridge University Press, 2003).

11 For more detailed discussions on the bloodiness of the Red Terror. see: J. Abbink, "The Impact of Violence: The Ethiopian "Red Terror" as a Social Phenomenon' in Peter J. Bräunlein and Andrea Lauser (eds), Krieg und Frieden: Ethnologische Perspektiven (Bremen: Kea-Edition, 1995); A. De Waal, Evil Days: Thirty Years of War and Famine in Ethiopia (London: Africa Watch/Human Rights Watch, 1991); J. Wiebel, "Let the Red Terror Intensify": Political Violence, Governance, and Society in Urban Ethiopia, 1976-78', International Journal of African Historical Studies, 48, 1, 2015, 13-30; B. Zewde, 'The History of the Red Terror: Contexts and Consequences', in K. Tronvoll, C. Schaefer, and G. A. Aneme (eds), The Ethiopian Red Terror Trials: Transitional Justice Challenged (Oxford: James Currey, 2009).

12 T. P. Ofcansky and L. V. Berry, Ethiopia, A Country Study. Federal Research Division Library of Congress, 1991. n.p.; and J. Wiebel, "Let the Red Terror Intensify': Political Violence, Governance, and Society in Urban Ethiopia, 1976-78", Durham University Online, 21 August 2015, 15 https://core.ac.uk/download/pdf/42127204.pdf. 
two-hundred acts of genocide and crimes against humanity that violated Article 281 of the Ethiopia's 1957 Penal Code (see below for more detail on this).

The Red Terror trials, as the prosecution of the members of the Derg is popularly referred to, began on 13 December 1994. According to Firew Tiba, a scholar of international law, the trials sought to 'address' the 'political upheaval that followed the 1974 revolution which brought down the several-thousand-year-old monarchy'. ${ }^{13}$ This mechanism of transitional justice operated much like the Nuremberg trials, in the sense that it was retributive in its approach, and was lodged within the judicial framework of the Ethiopian courts. ${ }^{14}$ As such, it was bound by criminal law. However, trials were not the only mechanism of retributive, transitional justice deployed in Ethiopia. ${ }^{15}$ Coupled with the trials was the lustration of 'members of the Derg regime and their collaborators. ${ }^{16}$ Having signed the UN Convention on the Prevention and Punishment of the Crime of Genocide ${ }^{17}$ in 1948, and ratifying it in 1949, but more significantly having included genocide as a criminal offense in its Penal Code (1957) the Ethiopian state was legally obliged to try former Derg officials who were accused of having committed or conspired to commit any of the acts constitutive of the crime of genocide.

The process toward prosecution began in 1992; 73 Derg officials were charged with the crime of genocide. However, of these, 14 died during the criminal proceedings, and 25, including Mengistu, had to be tried in absentia. Mengistu escaped incarceration by fleeing to Zimbabwe, where he was given political asylum and still lives. Many of the 73 were convicted of the crime of genocide, as well as human rights' violations and crimes against humanity, as provided for under Ethiopian and international law.

In the years since the dismantlement of the Derg, Ethiopia has enshrined terrorism as a criminal offence in its Anti-Terrorism Proclamation (No. 652/2009). This legislation textures the mens rea (intent) of acts of terrorism as intending to advance a political, religious or ideological cause by coercing the government, intimidating the public or a section of the public, or destabilizing or destroying the fundamental political, constitutional, economic or social institutions of the country. The idea of terror that permeates the legislation is further textured by the criminal acts that are listed as constituting the offence. These include causing a person's death or serious

13 See: F. K. Tiba, 'The Trial of Mengistu and Other Derg Members for Genocide, Torture and Summary Executions in Ethiopia', in C. Murungu and J. Biegon (eds), Prosecuting International Crimes in Africa (Pretoria: Pretoria University Law Press, 2014) http:// hdl.handle.net/10536/DRO/DU:30068884 (accessed September 2018)

14 On transitional justice, see R. G. Teitel, Transitional Justice (Oxford: Oxford University Press, 2000); R. G. Teitel, 'Transitional Justice Genealogy (Symposium: Human Rights in Transition)', Harvard Human Rights Journal, 16, 69, 2003, 69-94.

15 K. Tronvoll, C. Schaefer and G. A. Aneme 'The "Red Terror" Trials: The Context of Transitional Justice in Ethiopia' in Tronvoll et al (eds), The Ethiopian Red Terror Trials, 6; see also: G. A. Aneme, 'Apology and Trials: The Case of the Red Terror Trials in Ethiopia', African Human Rights Law Journal, 6, 2006, 64-84; and G. A. Aneme 'The Anatomy of Special Prosecutor v. Colonel Mengistu Hailemariam et al. (1994-2008), International Journal of Ethiopian Studies, 4, 1\&2, 2009, https://ssrn.com/ abstract $=2827180$ (accessed October 2018).

16 According to Heribert Adam and Kanya Adam, lustration can be understood as a process of politically charged bureaucratic screening, through which states undergoing political change 'disqualify' members or collaborators of the previous regime from holding public office. See H. Adam, and K. Adam, 'Politics of Memory in Divided Societies' in W. James and L. van der Vijver (eds) After the TRC: Reflections on the Truth and Reconciliation Commission in South Africa. (Cape Town: David Philip, 2000); see also Teitel, Transitional Justice; and Teitel, 'Transitional Justice Genealogy'.

Hereafter referred to as the Genocide Convention. 
bodily injury, kidnapping or hostage taking, and so on. However, this legislation was enacted only in 2009. At the time of the trials in the mid 1990s, no legal provisions allowed for members of the Derg and their interlocutors to be charged with terrorist acts. Further, international law has yet to adopt a coherent and 'universally' accepted definition of terrorism, although various pieces of legislation, including conventions, enshrine protection from and punishment for various acts which may constitute terrorism. This means that terrorism, as such, continues to evade the status of delicta juris gentium (breaching international law), and is punishable by law only in so far as locale-specific legislation provides for this.

Ethiopia is heralded not only as the first state to sign and ratify the Genocide Convention but for including the crime of genocide within its Penal Code as adopted in 1957. Article 281 of Ethiopia's Penal Code adapts and translates the original definition of genocide to specify, among a number of other features, the protection of political groups. This significant detail is discussed further below, but it is worth noting here that in the 1957 definition, genocide and crimes against humanity are not hierarchically ordered but are rendered equal insofar as the weight of the offence (and perhaps therefore the punishment) is concerned. However, since the collapse of the Derg (and possibly as a legacy of its proclamations), genocide and crimes against humanity now are entirely separated in Ethiopian law. The former remains within the country's Penal Code, while the latter is written into the Constitution of the Federal Democratic Republic of Ethiopia, as adopted in 1995.

Despite various requests by the Ethiopian state for Mengistu's extradition, the Mugabe regime refused to surrender the former head of state who was found guilty, along with over fifty members of the Derg regime, of 211 counts of genocide and crimes against humanity. According to Tiba, the Mugabe regime shielded behind the claim that surrendering Mengistu would be to facilitate his execution, as the death penalty is still administered in Ethiopia. As Tiba explains, the death penalty was reserved for persons who were deemed genocidaires - in the sense that they helped to plan, orchestrate and execute the orders of the regime, although this sentence was later commuted to life in prison for 23 of the former officials.

In 2011, however, the Ethiopian government granted an official pardon to 16 former Derg officials despite a judicial rejection of amnesty. The pardon was granted after the officials offered the Ethiopian public an apology, in consideration that, as Girmachew Alemu Aneme put it, 'apology results after a feeling of remorse over what happened. ${ }^{18}$

Genocide is the name given to the atrocities of the Red Terror by the eponymous trials that operated like a body of transitional justice after the Derg regime was dismantled in 1991. The naming of the Red Terror as genocide was provided for not by international law (which limits its definition to the intent to destroy 'racial, 
ethnic, national or religious groups as such $)^{19}$ but by the Ethiopian Penal Code, which also extends protection against the crime of genocide to members of political parties. This is perhaps a consequence of Ethiopia, until 2009, having no legislated protection against terrorism as a criminal offence, and there is, to date, no international convention on terrorism, per se.

The mental element of the crime of genocide, its mens rea, is shared by the Ethiopian Penal Code of 1957, the United Nations' Genocide Convention of 1948, and the International Criminal Court's Rome Statute, to the extent that the crime is articulated as committed with 'intent to destroy in whole or in part. ${ }^{20}$ The mens rea is what distinguishes genocide, and as such the figure of the genocidaire, from terrorism and the figure of the terrorist. Igor Primoratz delineates the mens rea of terrorism as 'the deliberate use of violence, or the threat of its use, against innocent people, with the aim of intimidating them, or other people, into a course of action they otherwise would not take. ${ }^{21}$ That is, the criminal intention that motivates terrorism is to intimidate persons into behaviours that they would otherwise be disinclined to. Said differently, the intention of genocide is to try to destroy a people, while terrorism is directed less at victims of the act and more at witnesses and survivors thereof.

In these terms, the Red Terror campaign was clearly also a terrorist one in the sense of aiming to subjugate people by forcing them to live with fear; and also to live with missing those who were made to disappear in places such as Bermuda house. This is, of course, a different kind of torture. These entangled genres of missingness are expounded through the RTMMM displaying the remains of some of the people killed during the Derg's bloody campaign.

The term 'genres', entangled with the literary and its accompanying disciplines, evokes notions of types, classes or kinds. However, traditional understandings of genre(s), as facilitated through categorisation and ordering, might suggest that one 'kind' of missingness is more severe than other(s) and, as such, more important. I use the term genre, not to invoke the notion of category, class or kind - all of which suggest that the objects that 'belong' in them are discrete, comparable and bound but rather to evoke the idea of example or expression. I use the term example in the sense articulated by Giorgio Agamben - that examples are part of a class precisely in the sense that they stand outside of it, not as exception, but as expression. In this sense, the genres of missingness staged through the RTMMM - the absence of basic forensic technologies hindering the identification of remains, and thus their return to bereaved families; the silences in the narratives of the persons disappeared

19 According to the definition provided in both the United Nations Convention on the Prevention and Punishment of the Crime of Genocide (1948) and the Rome Statute, genocide is any of five delineated acts 'committed with intent to destroy in whole or in part a racial, ethnic, national or religious group as such'. These acts are: 'killing members of the group; causing serious bodily or mental harm to members of the group; deliberately inflicting on the group conditions of life calculated to bring about its physical destruction in whole or in part; imposing measures intended to prevent births within the group; forcibly transferring children of the group to another group.

20 See: Penal Code of Ethiopia 1957 (Eritrean Transitional Penal Code), Proclamation No. 158 of 1957, 23 July 1957, http://www. refworld.org/docid/49216a0a2.html; UN General Assembly, Rome Statute of the International Criminal Court 17 July 1998 (amended 2010), http://www.refworld.org/docid/3ae6b3a84.html; and UN General Assembly, Convention on the Prevention and Punishment of the Crime of Genocide, 9 December 1948, United Nations, Treaty Series, http://www.refworld.org/ docid/3ae6b3ac0.html, (all accessed October 2018).

21 I. Primoratz, 'What is Terrorism?' Journal of Applied Philosophy, 7, 2, 1990, 129-138, 129. 
and of what became of them; and the missing that is the work of the bereaved - are expressions of missingness that are textured by the Ethiopian Red Terror.

What is at stake in understanding these modes of missingness as genres, examples or expressions, is a disruption of the hierarchical ordering that (directly and indirectly) privileges some victims over others. Furthermore, and consequently, it allows for the disruption of what Johannes Fabian calls 'the denial of coevalness. ${ }^{22}$ There is, explains Fabian, a difference between anthropology as practice and as discourse in their application of temporality, which he describes as schitzogenic. Insofar as the temporality of the practice of anthropology is concerned, which is to say in the actuality of fieldwork, the anthropologist and persons proxy of the culture of study are interlocutors in dialogue at the same time and in the same place. They are coeval, says Fabian. However, when translating this experience into discourse, the person proxy of an Other culture is made object by the temporal and spatial distance from the here and now of the anthropologist and the culture he (the subject of the modern episteme is male) is proxy for. Fabian calls this a denial of coevalness. In the context of the RTMMM, this denial is perhaps a consequence of the grand narrative or the absence of the forensic. Thus, to think of genres of missingness as examples or expressions, rather than types and kinds, allows victims of the Red Terror - both direct and in the broader sense of those who live with terror and the missingness of the disappeared - to refuse their positioning as then and there from the here and now but, instead, beckon a reckoning with a history, indeed a violence, that is not yet over.

\section{The Red Terror Martyrs' Memorial Museum}

The RTMMM stands on Addis Ababa's Africa Avenue, alongside then Revolutionary Square. The establishment of the museum was advocated for by various members of Ethiopian society, very many of whom had, in one way or another themselves, lived with the Derg. Purported to be independently established and run, the RTMMM relies on donations from visitors to the museum, although I imagine it makes a small profit from some of the texts that it sells, including The Day of the Martyrs, a collection of essays and articles published by G.W. Amanuel in 2010. ${ }^{23}$ According to one interlocutor, the Ethiopian state does not fund the institution, and 'stays out of the business of a museum'; others I met contested this.

The modernist style of the museum's facade, with its grey slate-like tiles and tinted-glass windows, is accompanied by a sculpture of three figures. At its base is a plaque that reads 'Never, ever again' - a gesture perhaps towards the contention that exists around how the atrocities committed by the Derg are named, as well as to the tensions between the provisions of the Ethiopian Penal Code, the Genocide Convention and the Rome Statute. The exterior is quite different to the belly of the institution, which is washed in a deep beige paint, further warmed by dim amber lighting.

2 J. Fabian, Time and the Other: How Anthropology Makes its Object ((New York: Columbia University Press, 1983).

Published in Addis Ababa by Banawe Press. 
The exhibition staged within this space takes the collapse of Emperor Selassie's reign as its point of departure. Depicted as a caricature of monarchic exorbitance, Selassie is shown blowing out candles on a birthday cake that resembles the monarch's crown. This image is juxtaposed with a photograph of an elderly man sitting on his haunches, his body withered away as a result of the famine that decimated most of rural Ethiopia in the early 1970s. The photograph of the old man is one of numerous similar images in the museum's first room. In the next move within its grand narrative, the RTMMM depicts the revolution of the early 1970s, in which activists from various walks of life called for the dismantling of the monarchy and the instatement of democratic rule. The revolution is depicted as having been a turning point in Ethiopian society, both away from monarchic rule and towards the bloodiness of the Derg regime. Accompanying images of the revolution are old pamphlets, including copies of Struggle, a resistance publication from the time; an old printing machine; soldiers' helmets and weapons; as well as other remnants of the time, all enclosed in glass cases.

\section{Articulations of torture: Bermuda and a puppet}

In the next space, demarcated and staged by the RTMMM, nestled between two desks and against a backdrop of bright scenes of cruelty, lies a prop, which I read as puppet, carved from wood and painted into living colour. The puppet is not quite upright, not quite on its back; its knees hinge atop a broomstick, its hands are married at the wrist by a telephone cord, and its feet are striped with red paint. It stands as metaphor for persons who were labelled as 'counter-revolutionary' by the Derg, subjected to wofe lala and disappeared during the Red Terror. ${ }^{24}$

This puppet / deconstructed language machine / three-dimensional literary object, ${ }^{25}$ is brought to performance by reading, as Edward Said might argue. ${ }^{26}$ This understanding of reading is made literal at the museum when a person, who identifies as survivor of the Red Terror, performs the wofe lala torture technique on the puppet, and rather disturbingly invites those present to participate by holding the whip, and touching the barbed wire. Wofe lala involves binding a person's wrists to

24 Although literature on the Ethiopian Red Terror, and particularly on the prosecution of its perpetrators, is scarce, there has been some engagement with the question of this irony, albeit often legal in its orientation. Consider for example a thesis submitted by Mengistu Worku Mengesha to the Central European University in 2008/2009, titled 'Delay of Justice in Ethiopia and the Genocide Trials of Derg Officials'. Mengesha's argument is orientated largely around a critique of how long the Red Terror trials took, as opposed to offering a reading of the conditions that led to their delay and indeed deferral. Similarly, Firew Tiba's work focuses largely on how the trials in Ethiopia were run and the question of justice in the wake of the Derg. Tiba uses the example of Mengistu's prosecution to offer a convincing critique of the genocidaire's prosecution and his evasion of (retributive) justice. However, Tiba also focuses on the legal framework within which the prosecution of 'terrorists' being charged with genocide is set. See: M. W. Mengesha, 'Delay of Justice in Ethiopia and the Genocide Trials of Derg Officials' (Thesis, Central University of Europe, 2008/2009); F. Tiba, 'The Mengistu Genocide Trial in Ethiopia', Journal of International Criminal Justice, 5, 2, 2007, 513-528; and Tiba, 'The Trial of Mengistu and Other Derg Members'.

25 Whether read in part or as a whole, the puppet is literary in the sense that it lends itself to a staging of questions beyond the limit of its form, and through its performance, it invites its readers not only to observe its articulation as an artefact but to abide by the politics of its place as proxy of the still-missing disappeared. Put differently, the puppet is literary in that it is not presented only as an artefact or even as a representation of an object, a thing, or an experience, but actually reads the problem of the missing in relation to violence and witness.

26 See E. Said, Power, Politics and Culture: Interviews with Edward Said (New York: Vintage, 2001); E. Said, 'The Text, the World, the Critic' Bulletin of the Midwest Modern Language Association, 8, 2, 1975, 1-23; E. Said, The World, The Text, The Critic (Cambridge, MA: Harvard University Press, 1983). 


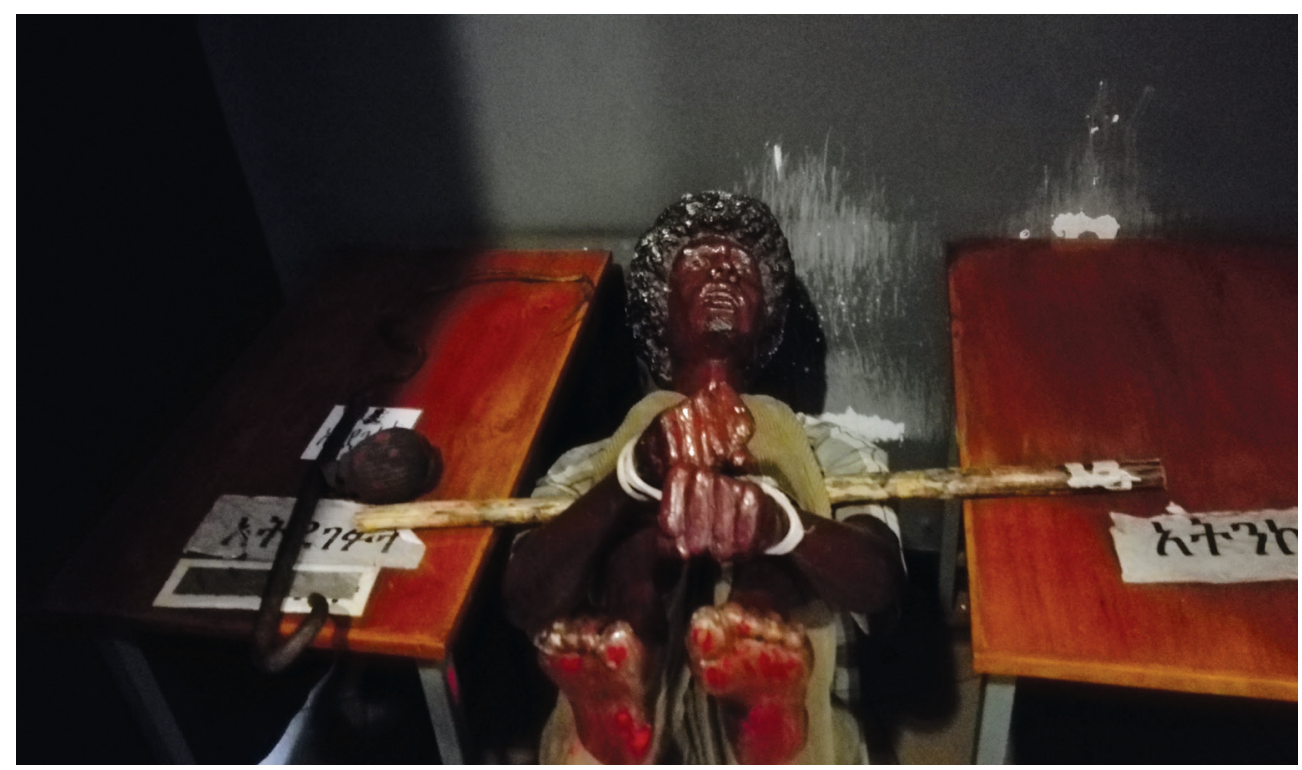

Figure 1: Puppet in the Red Terror Martyrs' Memorial Museum, 2018. Photograph by Lauren van der Rede

a wooden rod, bending their knees over another rod, and swinging them back and forth into the air. As their legs lift up, the soles of their feet are beaten with barbed wire or a whip reportedly made from 'hippo hide'.

The puppet is no one but also representative of everyone who disappeared in and around Addis Ababa between the years of the revolution and the dawning of the twenty-first century. In its performance as an intertextual object, the puppet produces a reading of the question of this violence, or more precisely of this terror, as always having been dually directed. By this I mean, and as Primoratz has argued, terror has two targets. ${ }^{27}$ The first is the direct target of a terrorist act, which includes killing, bodily harm, the forcible transfer of persons, and other acts that are also constitutive of the crime of genocide. In a campaign of terrorism, as noted earlier, the direct target is of secondary importance. That is, the indirect targets of acts of terror - he/she/they who are taken hostage through fear of being made a direct target - are of primary importance to the terrorist. In this sense, the disappeared are the vitally important mechanism through which survivors of terror are taken hostage.

From the testimonies of those who survived the Derg regime, ${ }^{28}$ and various literary readings of the problem such as Maaza Mengiste's Beneath the Lion's Gaze, ${ }^{29}$ we know that disappearance meant not only the destruction of the person disappeared,

See I. Primoratz, Terrorism: The Philosophical Issues (Basingstoke: Palgrave Macmillan, 2004); I. Primoratz, 'What is Terrorism?'. See, for example, testimonies recounted in Amnesty International, Human Rights Violations in Ethiopia: November 1978, AI Index, AFR 25/09/78, https://www.amnesty.org/download/Documents/204000/afr250101978en.pdf (accessed 25 November 2018); the various texts constitutive of Amanuel's Day of The Martyrs, and D. W. Giorgis, Red Tears: War, Famine and Revolution in Ethiopia (Trenton, NJ: Red Sea Press, 1989).

29 M. Mengiste, Beneath the Lion's Gaze: A Novel (New York: WW Norton, 2010). 
but also of their family, of the community, and as one interlocutor put it, of the social fabric of Ethiopia. ${ }^{30}$ As mentioned, families were made to pay a 'bullet fee' before they could retrieve the body of their deceased loved ones, which is to say that they were made to pay for the bullets that were used to murder their sons, daughters, fathers, mothers, and so on. A proclamation made mourning the loss of a person labelled 'counter-revolutionary' illegal. The punishment for such mourning was imprisonment, which often translated into disappearance, torture, and in the vast majority of instances, death.

What this puppet as literary object does is stage and enable an imagining of the lived experience of disappearance and torture under the Derg regime, differently to that staged and enabled through testimony. As text, the puppet allows the viewer, audience, reader to be coeval with the scripter of the torture and disappearance. The puppet, as text, is always present, and as such, is here and now, rather than then and there, from you and I; in so doing it stages the question of the limits of intervention and participation. By transforming the audience into a performer, the puppet in the moments of its performance deconstructs the schizogenic use of time that the discourse of genocide, like that of anthropology, enables. ${ }^{31}$

Across and about five meters away from the puppet and the chart mapping the torture houses in and around Ethiopia's capital, stands a replica of a prison cell, representative perhaps of a chamber typical of the torture houses - essentially a room with a wooden door that has what might have been a window carved out of it, stratified by thick metal bars. In another room, dark and claustrophobic, a mound of earth depicts a mass grave, and cupboards display the bones of some of what the guide posited as the over 50000 people killed during the Red Terror Addis Ababa alone. ${ }^{32}$ Of these, it was explained, only seven sets of remains have been identified. This points to a few things. First, that the bones have been found. Second, that no one is able to decode them - that the forensic experts are missing; and third, that the literary stands in their place.

The puppet or language machine is unlike most literary works, ${ }^{33}$ in the sense that I could not summon it to me, but had to take myself to it. As such, it is not available to me, to hold or play with (thankfully), to participate in or be coeval with. Rather it is my memory of my experience with the object that I read; a memory that I must trust will fail me at some point and hope that that failure, too, will be productive. Although we live in the age of the digital, and I have pictures, I can work with the object only as I remember it, in that moment of coevality, because it is its performance, more than its image, that haunts me.

30 Interview, name withheld for security reasons.

31 Fabian, Time and the Other.

32 Adding to this, another person at the museum noted that these 50000 people were murdered over the course of a single day and night.

33 The work, as we know from Roland Barthes, is bound, discrete and held in the hand, whilst the text is found in language, is irreducible in its plurality and is the product of the writer and the reader. Thus when I mark here that the puppet is unlike other works of literature, what I am suggesting is that it does not simply hold a space in the museum, like a book does in a library, but that it is a text - its meaning produced through its reading. 
This ghostly page in this grand narrative of the Ethiopian Red Terror exists betwixt the living and the dead, as both puppet and proxy of the disappeared who sit in the nouns, verbs and adjectives of its body, waiting to be expounded. And that is my task, to read this language machine, to deconstruct it and to allow it to make me its object as I have made it mine. We know from Roland Barthes, that a reader is both object and subject to the text, ${ }^{34}$ and the text is both subject and object to the reader. We also know from Althusser that the same relationship exists between the subject and ideology. ${ }^{35}$ That is, to expound the RTMMM language machine's irreducible plurality, I must abide by it as imposition and transformative mechanism - I must allow it to act on me through its performance. Having said this, I must acknowledge that this puppet, which made live those disappeared and presumed dead, is accessible to me now only through images taken there and then, and through my memory of its performance. It exists, but I can never have it; it is unique in the sense that like a page in a book, although it can be duplicated outside of its context - the narrative of the RTMMM - it stands in obscurity. The puppet is part of a narrative, etched across the walls and enclosed within the glass cases of the RTMMM, that it helps simultaneously to constitute and deconstruct.

In inviting audiences (guided tourists) to participate in the performance of the puppet, the guide may be attempting to evoke empathy for victims of torture. However, on a more abstract level, the invitation simultaneously invites viewers to empathise with the perpetrator. This dual 'identification' with both victim and perpetrator occurs because the puppet acts as a metaphor not only for the violence exacted against the disappeared but also as a proxy for such persons, some of whom, as the guide explained, disappeared in (or, as I prefer to put it, were disappeared to) the torture houses that littered Ethiopia's capital and surrounds.

Mazaa Mengiste's reading of the Derg making 'anti-revolutionaries' disappear, and various iterations thereof, including the torture of Berhane, a six-year-old boy, is particularly striking. While selling newspapers, the young boy is unknowingly implicated in an assassination. He is eventually questioned by a soldier and taken into custody but to his mother, brother, and Dr Hailu's family (around whom the narrative centres), he has disappeared, and they are not informed of his incarceration or his whereabouts. While in prison the child is tortured and interrogated:

Berhane sat strapped to a metal chair that was bolted to the ground. In front of him, two large men in uniform hunched over a box of long needles and ropes. One of them, the tallest, tugged at the two ends of a long rope and brought it close to Berhane's face. 'This one should work', he said. Berhane whimpered as he felt his legs lifted and tied to the chair ... Berhane's feet dangled, the end of the rope dragged on the floor. 
'Don't make me do this,' the man said. He petted Berhane's head ... The man pulled one of the long needles out of the box and waved it in front of him. 'Do you know what I'm going to do with this?' he asked. Berhane shook his head, too afraid to speak. He tried to jerk his arms free, but that made the rubber strap cut into him. The man put the sharp tip of the needle on his thigh. It felt cool and sharp against his skin. 'I'll push it all the way through. Do you know how much that'll hurt?' the man said.

Berhane saw the shorter man wipe his upper lip. 'Enough', the short man mumbled. He couldn't bring himself to meet Berhane's gaze. 'Enough, he doesn't know anything.' He slid the box closer to himself. 'He's telling the truth. Stop.'

The tall man turned around angry. 'He knows. They always know.'

He swept the needle through the air ... 'They think they can use kids now and we won't dare question them? He's not a child' - the man pointed at him. 'This is our newest enemy. ${ }^{36}$

There is a sinisterness, a sadism perhaps, in making believe that the torture the boy is about to endure is his own fault, that he was making the 'tall man' do this - a sinisterness which suggests that, in the mind of this soldier, the textures of difference have flattened out; he cannot distinguish between truth and lies, interrogation and torture, an innocent child and an enemy. This inability to distinguish guilty and innocent is, for Primoratz, the defining feature of the terrorist, who uses acts of terror (including torture certainly) to coerce people into courses of action they would otherwise not take. This aim is illustrated later in the text, when Berhane, having survived his torture, is marching in a row of boys who are cholding handmade signs against their bony hips ${ }^{37}$ - their bones indicating that they are malnourished, and subject to a kind of torture less bloody than others. Berhane cries 'Viva Guddu' (the character modelled on Mengistu) as he has been instructed to, but drops his sign, 'revealing angry, infected wounds on each leg. ${ }^{38}$ The fumble results in Berhane slowing down and falling behind the other boys, an offence serious enough that one of the soldiers will raise his rifle, and as Berhane looks up, scrambling to recover his sign, he sees the 'hollow-eyed stare of a gun and hear[s] his own sharp breath. The soldier pulls the trigger. ${ }^{39}$ In this moment, Berhane is transformed from a person who is of primary importance to this terrorist soldier, to a person of secondary importance. By this I mean that Berhane was first the subject of severe torture, which was motivated by the need for information but also by a desire to win the war (to indoctrinate or assimilate enemies) by creating in him fear so strong that he would surrender himself to the

\footnotetext{
Mengiste, Beneath the Lion's Gaze, 231-232.

Mengiste, Beneath the Lion's Gaze, 259.

Mengiste, Beneath the Lion's Gaze, 259.

Mengiste, Beneath the Lion's Gaze, 259.
} 
ideology of the regime. However, at the moment of his murder, Berhane becomes a target of the campaign of terror, and is thus of secondary importance. He is killed in front of other marchers so as to awaken in them such extreme fear that they surrender to the regime entirely lest they be next in line to die. The dead and disappeared served as a horrible warning for the general public, who were themselves shrouded in veils of suspicion, and prohibited from mourning their dead - from missing them publicly. Many of the bodies that adorned the streets of the city were accompanied by notes denouncing the deceased as enemies of the state and instructing their families and friends not to mourn for them, as staged in Mengiste's text. ${ }^{40}$

The torture, and in particular the making disappear, of political rivals or so-called counter-revolutionaries, was, like their murder in the homes and streets of Addis, a way of attacking the minds of the primary target, as a group. As such, the violence of terror, as performed by the military junta in Ethiopia, was, like genocide, not limited to its bloodiness. Rather, bloodiness is a means through which to achieve other violences, the most important of which is the generation of fear extreme enough to intimidate political opposition groups, and anyone affiliated with them, into submission for the purposes of subjugation. In this sense, terror is an attack on the mind of a group enabled through the often-extreme use of physical violence against members of a group. ${ }^{41}$

Another genre of missingness that the displayed remains point towards is that although the remains are present, the persons are still disappeared. Moreover, if the Derg allowed families who paid the required bullet fees to retrieve and bury - however unceremoniously - the remains of their deceased loved ones, those housed in the museum might be the bones of the hostage dead, which, to me, seem hostage still.

During the 'Missing and Missed' workshop, an interlocutor posited that there is something macabre about burying persons en masse in times of conflict that implies separating them from their families even in death. 'Why', she asked, 'can the dead not be returned to their families?' Perhaps something like an answer rests somewhere in the logic of what I call the commodification of death. By this I mean that a person is ascribed more value in death than in life, indeed perhaps more through death than through living. Within the logic of terrorism, the direct target of an attack endows

40 Dawit and Sara (Yonas' wife) are working together, along with the local shopkeeper Melaku, to gather the bodies of victims left on the streets of Addis Ababa. They take the bodies to a shed, deep in the forest of Mount Ntoto, where Melaku tries to identify the bodies so that families can be informed of the fate of their missing, and which they can then bury, although without ceremony. In one such venture, Dawit and Sara find the body of 'a barefoot boy lying faceup on the road, no more than fifteen years old.' Pinned to the boy's tattered shirt is a note that reads: 'I AM AN ENEMY OF THE PEOPLE. MOTHER, DON'T WEEP FOR ME, I DESERVED TO DIE', Later, Yonas finds Berhane's body on the street near their kebele (neighbourhood); Mengiste, Beneath the Lion's Gaze, 240. Many accounts from survivors of the Red Terror confirm that such messages were left on or beside dead bodies left in the streets of the Ethiopian capital. The narrative staged by the RTMMM offers one account; various scholars including Firew Tiba, and Edward Kissi have documented similar stories. See: Tiba 'The Mengistu Genocide Trial'; and E. Kissi, 'Remembering Ethiopia’s "Red Terror": History of a Private Effort to Preserve a Public Memory' in A. L. Mahoney, (ed.) Documenting the Red Terror: Bearing Witness to Ethiopia's Lost Generation, (Ottawa: Ethiopian Red Terror Documentation and Research Centre, 2012).

41 The proceedings of Prosecutor v Nahimana, Barayagwiza and Ngeze, of 3 December 2003, note: 'The association of the Tutsi ethnic group with a political agenda, effectively merging ethnic and political identity, does not negate the genocidal animus that motivated the Accused. To the contrary, the identification of Tutsi individuals as enemies of the state associated with political opposition, simply by virtue of their Tutsi ethnicity, underscores the fact that their membership in the ethnic group, as such, was the sole basis on which they were targeted'. This ruling, although abiding by the presiding legislation, suggests that where ethnically and politically determined convictions converge, the two cannot be considered discrete determinations of violence.' Case No. ICTR-99-52-T, para. 969, http://www.worldcourts.com/ictr/eng/decisions/2003.12.03_Prosecutor_v_Nahimana.pdf (accessed 25 November 2018). 
terrorists with the power to take additional hostages through fear, and by threatening them with a similar fate. What Mengiste illustrated in Beneath the Lion's Gaze is that, during the Red Terror in Ethiopia, fear was not lodged in death per se, but in the process of dying, which followed on the heels of disappearance.

Similarly, the grand narrative of the Red Terror etched across the walls of the RTMMM is perhaps most forcefully articulated through the photographs of the stillmissing disappeared. As the guide explained, it is hoped that these photographs, many of which resemble the kind used in identity documents, will someday be matched up with retrieved remains. No mention was made of returning the remains (and perhaps their accompanying photographs) to bereaved families. The seven sets of remains that have been identified are accompanied by photographs of the disappeared and deceased persons to whom they have been matched. These remains are displayed in individual cases inside a floor-to-ceiling cabinet, alongside other cases that contain numerous, often partial, sets of remains that also form part of the museum's permanent exhibit. Thus, the still-missing disappeared are such in the sense that their remains have been found and are no longer missing. But what has disappeared, and remains missing, are the details of the people, and their lived experience, as encapsulated in their names.

\section{Conclusion}

The tragic irony of the juxtaposition of the wofe lala puppet with the unidentified remains is that, although the museum posits what probably happened to the disappeared, and has some record of who they were, it cannot reconcile the two without the flattening effect of a grand narrative. As such, it cannot reconcile the missing with those who miss them. In this sense, as noted earlier, the puppet simultaneously constitutes and deconstructs the grand narrative of the Ethiopian Red Terror as articulated by the RTMMM. Through this process of deconstruction, this literary apparatus highlights the limits of the administration of (transitional) justice in Ethiopia, for although the museum cannot necessarily be expected to do the work of this kind of reconciliation, the state can well be.

As noted, although recognised as genocide according to the Penal Code of 1957, the Ethiopian Red Terror is not recognised as genocide according to its definition in international law. As a result, the Ethiopian judicial system, sapped of senior legal professionals, has had to resort to prosecuting some perpetrators, such as Mengistu, in absentia. In addition, some of those who were prosecuted and incarcerated for their crimes, were quickly granted amnesty as part of a presidential pardon.

The Red Terror trials were Ethiopias expression of a body of transitional justice that was retributive in its approach. According to Tiba, the trials sought to 'address' the 'political upheaval that followed the 1974 revolution which brought down the several-thousand-year-old monarchy', as a historical event. The Red Terror trials operated, much like those at Nuremberg, within the judicial framework of the Ethiopian courts. As such, they were bound by locale specific criminal law and as such were bound to prosecution of the heads and henchmen of the Derg regime. 
However, the trials were not the only mechanism of retributive, transitional justice deployed in Ethiopia while the Ethiopian People's Revolutionary Democratic Front was in power. ${ }^{42}$ Instead, as mentioned previously, the trials were coupled with the lustration of members of the Derg regime and their collaborators.

As the first state to sign the UN's Genocide Convention in 1948, and to ratify it in 1949 and having adopted the offense into its Penal Code, the State of Ethiopia was legally obliged to try former Derg officials who were accused of having committed or conspired to commit any acts constitutive of the crime of genocide. However, there is yet to be any official inquiry into the forced disappearance of persons during the rule of the Derg and particularly during the Red Terror. Similarly, no judicially sanctioned attempt has been made to identify or return the remains of those presumed murdered during the Red Terror to their families.

In the absence of these measures, the narrative embodied by the RTMMM puppet, in its literary reading of the Red Terror, comes to stand in their place. The RTMMM enables, as a mode of reading, a particular articulation of violence that is called terror by those who survived it, and named as genocide by those tasked with its redress. Performed as proxy for the disappeared, tortured and subjected, and taken as representative of those still missing, the puppet fills the void of the forensic. The irony of the Ethiopian Red Terror trials, as a body of transitional justice, is that persons marked as terrorists were prosecuted as genocidaires. Thus Ethiopia, as signifier, is bound up with the discourses of both terror and genocide, and stages the paradox of the relationship between genocide and terror. In so doing, it foregrounds all that slips between these two concepts, a space highlighted by a cut that is simultaneously constitutive of and carved out by the Red Terror trials as a mechanism of transitional justice - a cut seared into Ethiopia by the RTMMM. 